\title{
SarA based novel therapeutic candidate against Staphylococcus aureus associated with vascular graft infections
}

\author{
Rekha Arya $^{1}$, R. Ravikumar ${ }^{2}$, R. S. Santhosh ${ }^{3}$ and S. Adline Princy ${ }^{1 *}$ \\ ${ }^{1}$ Quorum Sensing Laboratory, Centre for Research on Infectious Diseases, School of Chemical and Biotechnology, SASTRA \\ University, Thanjavur, India, ${ }^{2}$ Department of Chemistry, SASTRA University, Thanjavur, India, ${ }^{3}$ Genetic Engineering Laboratory, \\ Centre for Research on Infectious Diseases, School of Chemical and Biotechnology, SASTRA University, Thanjavur, India
}

OPEN ACCESS

Edited by:

Marta Martins,

University College Dublin, Ireland

Reviewed by:

Yuji Morita,

Aichi Gakuin University, Japan

Dinesh Sriramulu,

Shres Consultancy

(Life Sciences), India

*Correspondence:

S. Adline Princy,

Quorum Sensing Laboratory, Centre for Research on Infectious Diseases (CRID), School of Chemical and Biotechnology, SASTRA University, Thirumalaisamudram, Thanjavur 613401, India adlineprinzy@biotech.sastra.edu

Specialty section:

This article was submitted to Antimicrobials, Resistance and Chemotherapy,

a section of the journal Frontiers in Microbiology

Received: 10 January 2015 Accepted: 20 April 2015 Published: 06 May 2015

Citation: Arya R, Ravikumar R, Santhosh RS and Princy SA (2015) SarA based novel therapeutic candidate against Staphylococcus aureus associated with vascular graft infections.

Front. Microbiol. 6:416.

doi: 10.3389/fmicb.2015.00416
Staphylococcus aureus is a common pathogen seen in prosthetic vascular graft, leading to high morbidity and mortality. The virulence genes for severity of infections are under the control of global regulators. Staphylococcal accessory regulator A (SarA) a known master controller of biofilm formation is an attractive target for the drug development. A structure based screening of lead compounds was employed for the identification of novel small molecule inhibitors targeted to interact to the DNA binding domain of the transcriptional activator, SarA and hinder its response over the control of genes that up-regulate the phenotype, biofilm. The top-hit SarA selective inhibitor, 4-[(2,4-diflurobenzyl)amino] cyclohexanol (SarABI) was further validated in-vitro for its efficacy. The SarABI was found to have $\mathrm{MBIC}_{50}$ value of $200 \mu \mathrm{g} / \mathrm{ml}$ and also down-regulated the expression of the RNA effector, (RNAIll), Hemolysin (h/d), and fibronectin-binding protein (fnbA). The anti-adherence property of SarABI on $S$. aureus invasion to the host epithelial cell lines (Hep-2) was examined where no significant attachment of $S$. aureus was observed. The SarABI inhibits the colonization of MDR S. aureus in animal model experiment significantly cohere to the molecular docking studies and in vitro experiments. So, we propose that the SarABI could be a novel substitute to overcome a higher degree of MDR S. aureus colonization on vascular graft.

Keywords: Staphylococcus aureus, multi drug resistance, SarA, quorum sensing, molecular docking, virulence gene expression, vascular graft associated infection

\section{Introduction}

Staphylococcus aureus is the most commonly isolated pathogen in the prosthetic vascular graft implanted in patients and uses a synchronized multiple virulence gene expression to establish infection in humans (Legout et al., 2012) and leads to organ failure, and death particularly in immunocompromised patients (Barnes and Chetter, 2012). The associated infections cause severe clinical threat because of the greater morbidity and mortality related to its opportunistic behavior (Lister and Horswill, 2014). S. aureus colonizes in prosthetic grafts to form a remarkable multilayer biofilm that is very difficult to treat clinically since the bacterial cells within the biofilm are resistant to the host immune response and antibiotic agents (Daghighi et al., 2013). 
Various pathways have been elucidated in $S$. aureus that are linked with its pathogenicity and virulence gene expression. The RNAIII is the intracellular effector of the agr quorum sensing mechanism to coordinate a large number of virulence determinants including cell-wall-associated proteins and exoproteins. (Cheung et al., 2004). The sar locus encodes a DNA-binding protein SarA; a $14.7 \mathrm{kDa}$ winged helix turn helix transcriptional activator and known to up-regulate the agr based quorum sensing system to elicit the exoprotein level (Cheung et al., 2004; Beenken et al., 2010). Simultaneously, the SarA indirect role on down-regulation of various other regulatory loci such as rot, sarS, sarV, sarT are well documented (Arya and Princy, 2013a). The DNA binding studies have revealed that the SarA binds to the intergenic region of $\mathrm{P} 2$ and $\mathrm{P} 3$ promoters of the agr locus and modulates the downstream genes such as hla and spa that encodes alpha hemolysin and protease respectively (Chien et al., 1999). But, the stable expression of both the genes in agr null strains strongly suggest the role of SarA on modulating its target gene expression either in direct or indirect manner (Cheung et al., 2008). Furthermore, SarA is also involved in the $a g r$-independent expression of several other virulence genes including $f n b A$ (fibronectin binding protein A), TSS (toxic shock syndrome) and icaRA (coagulase)and bap (biofilm associated proteins). Trotonda et al. (2005), Roberts et al. (2006), Andrey (2010) and Arciola et al. (2012). Existing antibacterial treatments for prosthetic vascular graft associated infections are inadequate due to the emergence of multi-drug resistance thus emphasing the need for combinatorial and higher dose therapy (Legout et al., 2014). So, there is a strong necessity for the novel therapeutic compounds to overcome antimicrobial resistance. In the current era few selective anti-virulent candidates have been revealed as a potent inhibitor of $S$. aureus agr based infections (Kiran et al., 2008; Sully et al., 2014). Targeting the SarA-DNA interaction has resulted in the identification of the first novel and extremely selective inhibitor that can efficiently suppress the staphylococcal infections. Hence, in an effort to develop an alternative treatment, several drug like molecules were designed and evaluated to assess their potentiality to overcome the pathogen responses to host tissues. Our study also demonstrates the advancement of research in this direction of exploiting the quorum regulator and score a novel potent SarA selective therapeutic candidate to dodge the $S$. aureus pathogenesis.

\section{Material and Methods}

\section{Bacterial Isolates and Growth Conditions}

S. aureus (105 strains) were isolated from rejected vascular graft (KAP Viswanatham Government Medical College, Trichy, India) and analyzed for the expression of virulence genes including antibiotic resistance, hemolysin production, biofilm formation and protease production. The strains that exhibited a higher degree of expression on those virulence factors were used for the drug efficacy analysis. To analyze the antimicrobial resistance pattern, the antibiotics such as penicillin, azithromycin, vancomycin, cefazolin, clindamycin, cloxacillin, erythromycin and teicoplanin were used in the study. The ATCC 25923 and mutant strains [Newman $\Delta$ agr::tetM, Newman sarA::Tn917LTV1, Newman $\Delta$ agr::tetM, sarA::Tn917LTV1] were grown aerobically at $37^{\circ} \mathrm{C}$ in tryptic soy broth (HiMedia, laboratories, India) overnight and the cultures were stored for further use (Table 1).

For broth culture, the $S$. aureus strains were grown in tryptic soy broth and the culture was incubated at $37^{\circ} \mathrm{C}$ with constant shaking at $200 \mathrm{rpm}$ and the cells were harvested at exponential phase. The growth rate was measured spectrophotometrically at $600 \mathrm{~nm}\left(\mathrm{OD}_{600}\right)$. Wolz et al. (2000), Boles et al. (2010), Chen et al. (2011), Coraça-Huber et al. (2012).

\section{Computational Methods}

Structure assisted drug designing and molecular docking was used to design several drugs like molecules against the SarA DNA binding sites. Briefly, the 3-dimensional X-ray crystal structure of SarA was retrieved from the protein data bank [Accession ID: $2 \mathrm{FRH}$ ] and further processed. The three amino acids D88, E89, and R90 responsible for conferring its binding to DNA (DNA binding domain) was selected as the target residues for the molecular docking analysis and the interactions of SarA with ligands formed the basis for design and scoring. Liu et al. (2006) and Arya and Princy (2013b).

The leads were subjected to the refinement as it improved their specificity, physiochemical properties including absorption, distribution, metabolism, excretion (ADME), and toxicity profile.

\section{Synthesis of SarA Based Biofilm Inhibitor (SarABI)}

The SarABI was synthesized by the condensation of commercially available 2,4 difluorobenzyl bromide and 4-aminocyclohexanol (Sigma-Aldrich) (Scheme-1).
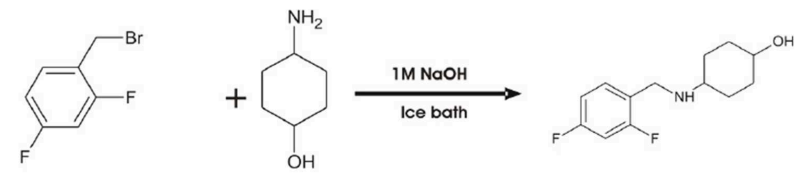

2. 4 difluorobenzyl bromide

4-aminocyclohexanol

4-[[2,4-difluorobenzy|)amino]cyclohexanol

The condensation reaction was carried out on an ice bath in the presence of $\mathrm{NaOH}$ with constant stirring for $3 \mathrm{~h}$. The reaction mixture was extracted with ethyl acetate. The pooled organic layers were washed successively and then washed with $10 \%$ $\mathrm{HCl}, 10 \%$ potassium carbonate and with brine, and dried over anhydrous magnesium sulfate. The formation of the SarABI was confirmed with proton and carbon nuclear magnetic resonance spectra followed by the gas chromatography mass spectra. The presence of hydroxyl group was confirmed by $\mathrm{D}_{2} \mathrm{O}$ exchange and Fourier transforms infrared spectroscopy (FT-IR using KBr).

\section{in-vitro Analysis of SarABI Efficacy Minimum Biofilm Inhibitory Concentration (MBIC)}

A biofilm susceptibility assay (MBIC) was used to quantify the anti-biofilm activity of SarABI. S. aureus strains were grown overnight in TSB, diluted $1: 100$ in fresh TSB medium and grown to early exponential phase $\left(\mathrm{OD}_{595}=0.2\right)$. Then $100 \mu \mathrm{l}$ (approximately $2 \times 10^{7}$ bacteria) of the culture were applied to sterile polystyrene 96 -well plates along with 2-fold dilution series of SarABI and untreated culture was used as a control. The assay plates were incubated for $18 \mathrm{~h}$ at $37^{\circ} \mathrm{C}$ and then non-adherent cells were removed on repeating the washing 
TABLE 1 | Bacterial strains used in this study.

\begin{tabular}{|c|c|c|}
\hline Strain & Relevant genotype or phenotype & Reference/source \\
\hline ATCC 25923 & clinical isolate & ATCC \\
\hline ALC 355 & Newman $\Delta$ agr::tetM & 11 \\
\hline ALC 637 & Newman, sarA::Tn917LTV1 & 11 \\
\hline ALC 638 & Newman $\Delta$ agr::tetM,sarA::Tn917LTV1 & 11 \\
\hline $\begin{array}{l}\text { QSLSA1051, QSLSA1052, QSLSA762, QSLSA764, } \\
\text { QSLSA782, QSLSA785, QSLSA1061, QSLSA 1068, } \\
\text { QSLSA 1149, QSLSA95, QSLSA1097 }\end{array}$ & Wild type laboratory strain & This work \\
\hline
\end{tabular}

step with phosphate buffered saline. The cells adhered to the polystyrene plates were stained with $50 \mu \mathrm{l}$ of $0.06 \%$ crystal violet and the optical density was read at $600 \mathrm{~nm}$ to quantify the extent of biofilm formation. The concentration of the SarABI was used in a serial 2-fold dilution that could inhibit the biofilm formation by $50 \%\left(\mathrm{MBIC}_{50}\right)$ and $90 \%\left(\mathrm{MBIC}_{90}\right)$ compared to the untreated control (Opperman et al., 2012). The calculated $\mathrm{MBIC}_{50}$ and MBIC $_{90}$ data were used in all the subsequent experiments to analyze the efficacy of SarABI.

\section{Antimicrobial Activity Assay}

S. aureus strains were grown overnight in TSB and diluted 1:100 in fresh TSB to reach early exponential phase of growth. Then $100 \mu \mathrm{l}$ of this culture was applied to sterile 96-well polystyrene plates without or with the effective concentrations of SarABI $\left(\mathrm{MBIC}_{50}\right.$ and $\mathrm{MBIC}_{90}$ ) was observed at $200 \mu \mathrm{g} / \mathrm{ml}$ and $1 \mathrm{mg} / \mathrm{ml}$ respectively). Cultures were grown without shaking for $24 \mathrm{~h}$ at $37^{\circ} \mathrm{C}$ and the optical density was measured at $595 \mathrm{~nm}$, then $100 \mu \mathrm{l}$ of culture were plated on to TSA for determining the colony forming units (Kiran et al., 2008).

\section{Hemolysin Production}

Hemolytic activities of the SarABI were determined using rabbit erythrocytes. S. aureus were cultured overnight and diluted $\mathrm{OD}_{600}=0.1$ in $20 \mathrm{ml}$ of fresh TSB and incubated for $3 \mathrm{~h}$ at $37^{\circ} \mathrm{C}$ till an approximate $\mathrm{OD}_{600}$ of 0.6 . The cells were collected by centrifugation at $10,000 \times \mathrm{g}$ for $10 \mathrm{~min}$ at $4^{\circ} \mathrm{C}$ and re-suspended in $20 \mathrm{ml}$ of phosphate buffer saline (PBS). The $2 \%$ erythrocytes were prepared on centrifuging $1 \mathrm{ml}$ of fresh de-fibrinated blood $(1620 \times \mathrm{g}, 10 \mathrm{~min})$ and the pelleted cells were re-suspended in $1 \mathrm{ml}$ sterile PBS. The cells were repeatedly washed with PBS and re-suspended in $0.75 \mathrm{ml} \mathrm{PBS}$ and $2 \%$ erythrocyte suspension. Further $100 \mu \mathrm{l}$ of the bacterial culture with or without SarABI $\left(\mathrm{MBIC}_{50}\right.$ and $\left.\mathrm{MBIC}_{90}\right)$ as independent experiments were mixed with $900 \mu \mathrm{l}$ of $2 \%$ red blood cells and incubated at $37^{\circ} \mathrm{C}$ for $3 \mathrm{~h}$. The aliquot were centrifuged and the percent hemolysis was measured at an optical density of $540 \mathrm{~nm}$ (De Latour et al., 2010; Dean et al., 2011).

\section{Bacterial Cell Adherence}

Labeling S. aureus with fluorescein isothiocyanate (FITC) The multi-drug resistant clinical isolates and reference strain were grown to early exponential phase. Cell pellets were re-suspended in PBS and sodium bicarbonate buffer with Fluorescein isothiocyanate (FITC) $(1.0 \mathrm{mg} / \mathrm{ml}$; Sigma Aldrich). The cells were incubated overnight at $4^{\circ} \mathrm{C}$ with gentle stirring and further washed with sodium bicarbonate buffer (Hochbaum et al., 2011).

\section{Cell adherence}

The FITC labeled S. aureus cells were diluted 1:100 in PBS. $100 \mu \mathrm{l}$ of cells $\left(2 \times 10^{7}\right)$ were applied to sterile cover slides in 12 well polystyrene plates with or without SarABI (at its effective concentration) and incubated for $30 \mathrm{~min}$ at $37^{\circ} \mathrm{C}$. Thereafter cover slides were repeatedly washed with $\mathrm{PBS}$ and fluorescence determined at $485 / 530 \mathrm{~nm}$ (Zeiss AxioA1, Progress C5) (Bose et al., 2012).

\section{Bacterial attachment to polystyrene in vitro}

Briefly $S$. aureus strains were grown to the early exponential phase with $\mathrm{OD}_{595} \mathrm{~nm}=0.2$ (contains $2 \times 10^{7}$ bacteria). To analyze the cell attachment, $100 \mu \mathrm{l}$ of the bacterial culture was taken in sterile 96 wells polystyrene plate with or without SarABI (at its effective concentration). Cells were grown for $3 \mathrm{~h}$ at $37^{\circ} \mathrm{C}$ and the unbound cells were removed on repeated washing with phosphate-buffered saline. The cells were air-dried and fixed with $100 \%$ ethanol and stained for 2 min with $0.4 \%$ gentian violet where the excess stains were removed on washing with PBS. A $100 \mu \mathrm{l}$ of $1 \%$ sodium dodecyl sulfate (SDS) was added to each well to solubilize the stained cells. The optical density was measured at $\mathrm{OD}_{595}$ in 96 well plate reader (Biorad Plate Reader, Bio-Rad, Hercules, CA, USA) (Gov et al., 2001; Krut et al., 2003).

\section{Confocal laser scanning microscope (CLSM) of static biofilm}

Static biofilms were grown in a 8-well cover glass plates (Nunc, Wiesbaden, Germany) was subjected to analysis using confocal microscope (Olympus America, Inc., Melville, NY) after gentle washing and staining with fluorescent isothiocyanate $(0.1 \%$ in PBS) for $15 \mathrm{~min}$. The cells were washed twice in PBS and the developed biofilms were analyzed at excitation and emission wavelength 488 and $520 \mathrm{~nm}$ respectively by adjustable spectrum slit (Periasamy et al., 2012). Further the COMSTAT (Biofilm Image Processing Tool) was used to analyze the biofilm thickness, roughness, bio-volume and minimum colony size at the substratum.

\section{Quantitative Real Time-PCR (qRT-PCR)}

The total RNA was isolated from the SarABI (at its effective concentration) treated and untreated cells using guanidinium thiocyanate (Chomczynski and Sacchi, 2006). 
The single step qPCR experiment was performed in a realtime cycler using SYBR Green method (Genotypic technology, India). The $f n b A$, hld and RNAIII expression patterns were determined using the following primers: $5^{\prime}$ - TGCAAATACGAC AGATACTT-3' (forward), 3'-TTGGCCACCTTCATAACCTA-5' (reverse), $5^{\prime}$-ATGATCACAGAGATGGTA-3' (forward), $3^{\prime}$-CTG AGTCCTAGGAAACTAACT-5' (reverse), $5^{\prime}$-CTGAGTCCTAG GAAACTAACTC-3' (forward), 3'-TGATCACAGAGATGTGA$5^{\prime}$ (reverse). Relative levels (RL; \%) of fnbA, hld and RNAIII transcripts were calculated using comparative Ct method and normalized to those of arc (carbamate kinase- house-keeping gene) transcript expression (Wolz et al., 2000).

\section{Rat Graft in-vivo Infection}

The animal experiments were performed according to the experimental practices and standards developed by the animal welfare also with the prior approval from the Institutional Animal Ethics Committee (IAEC). Adult male Wistar rats (812 weeks) were used in the study, as it includes two series consisting of seven groups. Sterile collagen sealed double velour knitted polyethylene terephthalate (PET; Dacron) graft was used as the medical device in these experiments. For the animal experiments, the control group (disease control, DC) implanted with the unsoaked grafts and the experimental groups (infected either with the clinical isolates or the mutant strains) were implanted with SarABI soaked grafts as independent experiments were maintained. All rats were subjected to a minor surgery to make a subcutaneous pocket on each side of the median line by a $1.5 \mathrm{~cm}$ incision. All grafts were explanted after 15 days of implantation and biofilm formation was analyzed by determining the colony forming units. Various biochemical parameters such as albumin, ALT (alanine aminotransferase), ALP (alkaline phosphatase), AST (aspartate aminotransferase), direct bilirubin, total bilirubin, total protein, creatinine and urea were determined to analyse the toxicity of drug (Wang et al., 2011).

\section{Histophalogy and Bacterial Count}

Wistar rats were sacrificed after 15 days where the tissues from the graft site, liver, kidney, spleen, PET grafts and blood samples were collected. The tissue samples were further analyzed histopathlogically as well as processed for bacterial count. For histopathogical analysis, tissues were fixed in $10 \%$ formalin and sliced into a thickness of $2.1 \mathrm{~mm}$. The tissues were then dehydrated with alcohol of graded concentrations. Subsequently the samples were cut on a microtome to $5 \mu \mathrm{m}$ and stained with haematoxylin-eosin. The stained samples were examined under a light microscope; and photomicrographs of the samples were recorded (Bellows et al., 2011).

For bacterial count from various tissues, the samples were homogenized in PBS and serially diluted samples were then plated on $5 \%$ sheep blood agar plates. Similarly, $100 \mu$ l of blood samples were also cultured on blood agar plates. The collected PET grafts were sonicated in PBS so as to detach the adherent bacterial cells and the samples were cultured on blood agar plates to count bacterial cells (Aboshady et al., 2012).

\section{Cytotoxicity Assay}

The chemo-sensitivity of HEp-2 cells were determined using [3(4, 5-dimethyl thiazol-2yl)-2, 5-diphenyl tetrazolium bromide] (MTT) standard assay. Briefly HEp- 2 cell line $\left(2 \times 10^{6}\right.$ cells $\left./ \mathrm{ml}\right)$ was seeded in 96-well plate. The adherent cells were grown to confluences for $24 \mathrm{~h}$ to allow cell attachment. The effective concentration of SarABI was added to each well and incubated for $72 \mathrm{~h}$. The MTT solution was added and the cell viability was measured at $540 \mathrm{~nm}$ (George et al., 2012).

\section{Adherence Assay to HEp-2 Cell}

Clinical isolates and mutant strains of $S$. aureus cells were labeled with fluorescein isothiocyanate (FITC) as described earlier (Balaban et al., 2003). To assess S. aureus adherence to HEp-2 human epithelial cells culture was applied to 8well cover glass plates and allowed to grow at $37^{\circ} \mathrm{C}$ in a $5 \%$ $\mathrm{CO}_{2}$ incubator in bicarbonate-buffered dulbecco modified eagle medium (DMEM) (Sigma-Aldrich, USA) supplemented with $5 \%$ fetal calf serum (FCS) (Himedia. laboratories, India) to reach confluency $\left(2 \times 10^{5}\right.$ cells $\left./ \mathrm{ml}\right)$. FITC-labeled $S$. aureus $\left(2 \times 10^{6}\right.$ cells/well in $90 \mu \mathrm{L}$ PBS $)$ were added to the confluent layer of HEp-2 cell line with or without SarABI at its effective concentration. S. aureus and HEp-2 cells were incubated for $30 \mathrm{~min}$ at $37^{\circ} \mathrm{C}$ and further washed with PBS and the intensity of fluorescence was determined at $485 / 530 \mathrm{~nm}$ under the CLSM.

\section{Statistical Analysis}

Statistical analysis was carried out using graph pad prism software (version 4.03). One-Way ANOVA was used, followed by Newman-Keuls multiple comparison test using GraphPad prism program version 6.0 (Graph Pad Software Inc., San Diego, CA). The minimum level of significance was set at $P=0.001$. All assays were conducted in triplicates and statistical analysis was done.

\section{Results}

\section{Design and Synthesis of Novel SarA Based Inhibitor (SarABI)}

A pool of several hits was generated that could favorably interact to the DNA binding site of SarA using the de novo evolution mode of the program (Liu et al., 2006). The top-hit ligand was selected according to their relative energies, docking score, molecular and pharmacokinetic properties. The docking analysis revealed that the SarABI forms hydrogen bond with glutamic acid and arginine at 88 and 89 positions respectively. The reaction sequence leading to the formation of desired SarABI as outlined in scheme-1 yielded $72 \%$ of the compound. The presence of the hydroxyl group at characteristic position and number of protons (Figure S1) and carbons, the presence of benzene and cyclohexanol ring was confirmed (Figure S2). The $\mathrm{D}_{2} \mathrm{O}$ exchange and FTIR spectra confirmed the presence of amide and hydroxyl moiety in the SarABI (Figure S3). A corresponding molecular weight of 241 was confirmed with the GC-MS (Figure S4). 


\section{Determine SarABI Minimum Biofilm Inhibitory Concentration (MBIC)}

The concentration of a drug required to either reduce $50 \%$ of biofilm deposition $\left(\mathrm{MBIC}_{50}\right)$ or inhibit the biofilm formation up to $90 \%$ ( $\mathrm{MBIC}_{90}$ ) was used as a standard for the assessment of

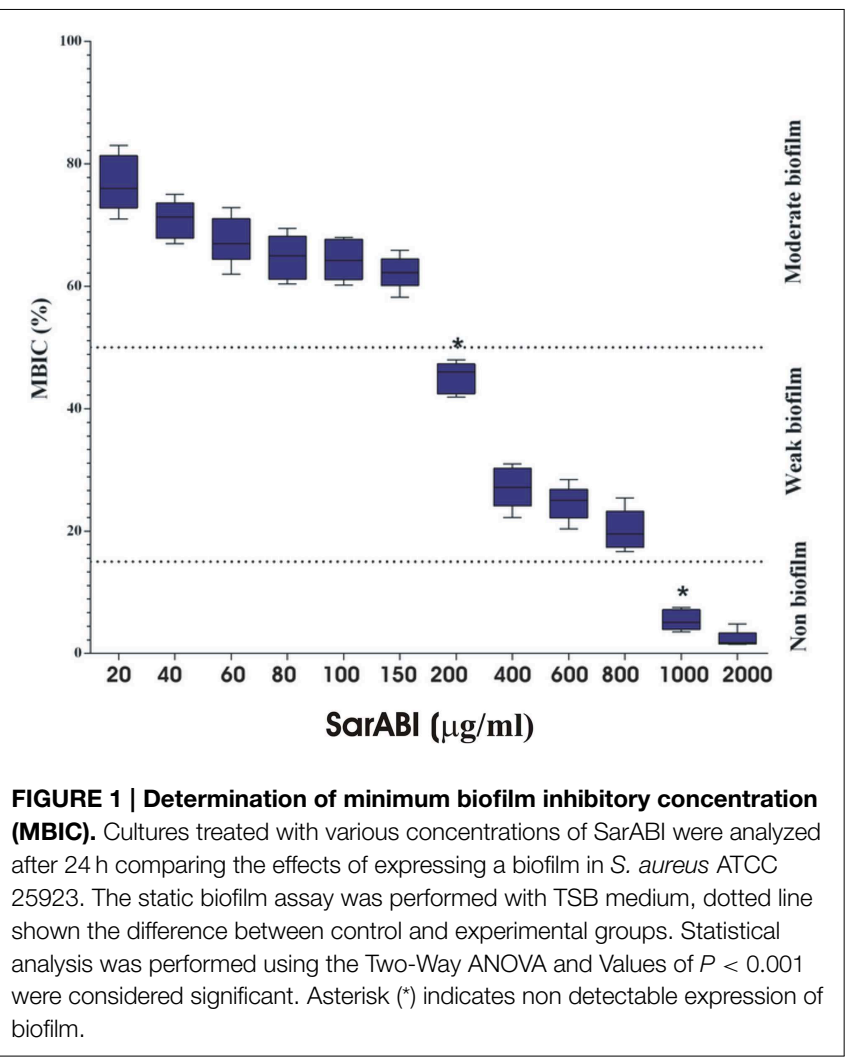

SarABI sensitivities for multi-drug resistantS. aureus. The effect of SarABI on the biofilm formation at various concentrations were analyzed and it was observed that the reduction was prominent in a concentration-dependent manner. The SarABI exhibited an inhibitory effect on the development of $S$. aureus biofilm with $\mathrm{MBIC}_{50}$ of $200 \mu \mathrm{g} / \mathrm{ml}$. No significant biofilm formation was observed in any of the clinical isolates when incubated with SarABI at a concentration of $1 \mathrm{mg} / \mathrm{ml}$ of the growth medium prior to inoculation (Figure 1).

\section{SarABI Efficiently Act on Bacterial Growth and Hemolysin Production}

The drug, SarABI was designed to repress the expression of virulence genes, including biofilm formation and hence, did not exert any kind of selective pressure on bacteria to become resistant. The results obtained from colony forming units clearly indicated that SarABI did not exhibit antibacterial activity against $S$. aureus. The in-vitro antibacterial activity of SarABI with reference to its optimal concentration of MBIC $_{50}(200 \mu \mathrm{g} / \mathrm{ml})$ and $\mathrm{MBIC}_{90}(1 \mathrm{mg} / \mathrm{ml})$ were tested on multiple drug resistant $S$. aureus strains. The study clearly indicated that the SarABI did not exhibit antibacterial activity against these strains up to the tested concentration of $1 \mathrm{mg} / \mathrm{ml}$ (Figure 2).

As shown in Figure 3, hemolysin activity was significantly decreased in the clinical isolates and agr mutant strain (Newman $\Delta$ agr::tet $M$ ) when treated with SarABI but considerably increased in the sarA mutant (Newman sarA::Tn917LTV1) as compared to the control. These results are consistent with the data that the SarABI shows SarA selective suppression of the biofilm formation. The hemolytic activity of the clinical isolates and mutant strains were also tested and it was found that $200 \mu \mathrm{g} / \mathrm{ml}$ of SarABI had reduced the hemolytic activity to $50 \%$ and $>100 \%$ was observed as the drug (SarABI) dose was increased to $1 \mathrm{mg} / \mathrm{ml}$.

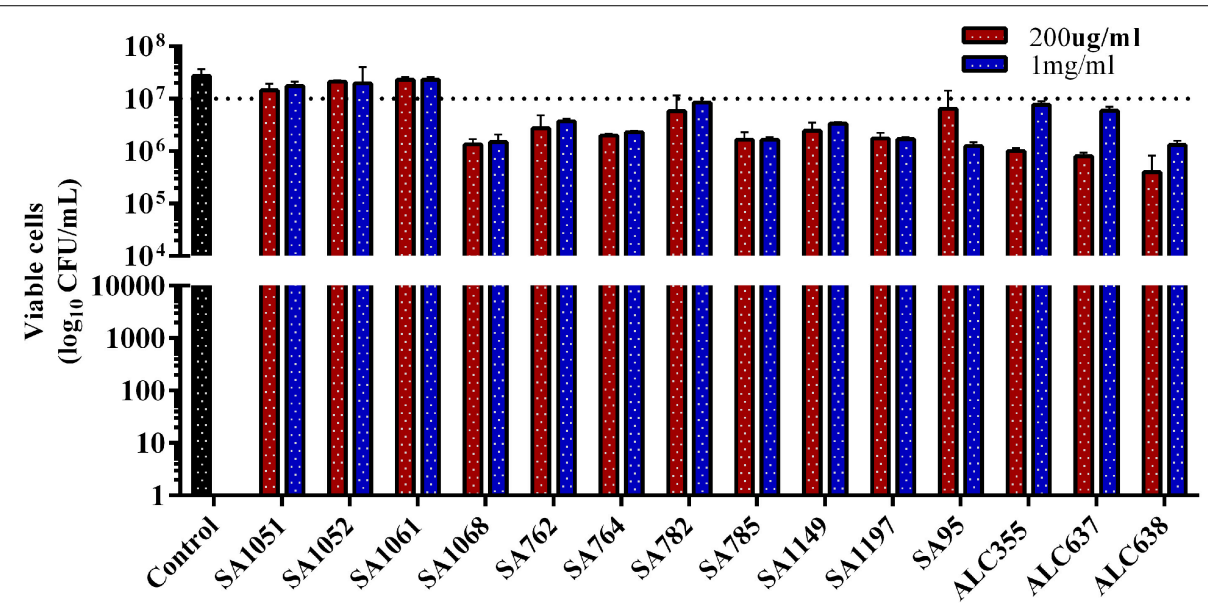

S. aureus strains

FIGURE 2 | Colony forming unit assays of clinical isolates and mutant strains of $\boldsymbol{S}$. aureus. The strains were incubated for $24 \mathrm{~h}\left(2 \times 10^{7} \mathrm{cfu} / \mathrm{ml}\right)$ with the addition of $200 \mu \mathrm{g} / \mathrm{ml}$ and $1 \mathrm{mg} / \mathrm{ml}$ SarABl in tryptic soy agar plates which does not affect the viability of clinical isolates compared to control. A similar effect was observed in mutant laboratory strains (ALC355, ALC637, ALC638), dotted line shown the difference between control and experimental groups. Statistical analysis was performed using the Two-Way ANOVA and Values of $P<0.001$ were considered significant. 


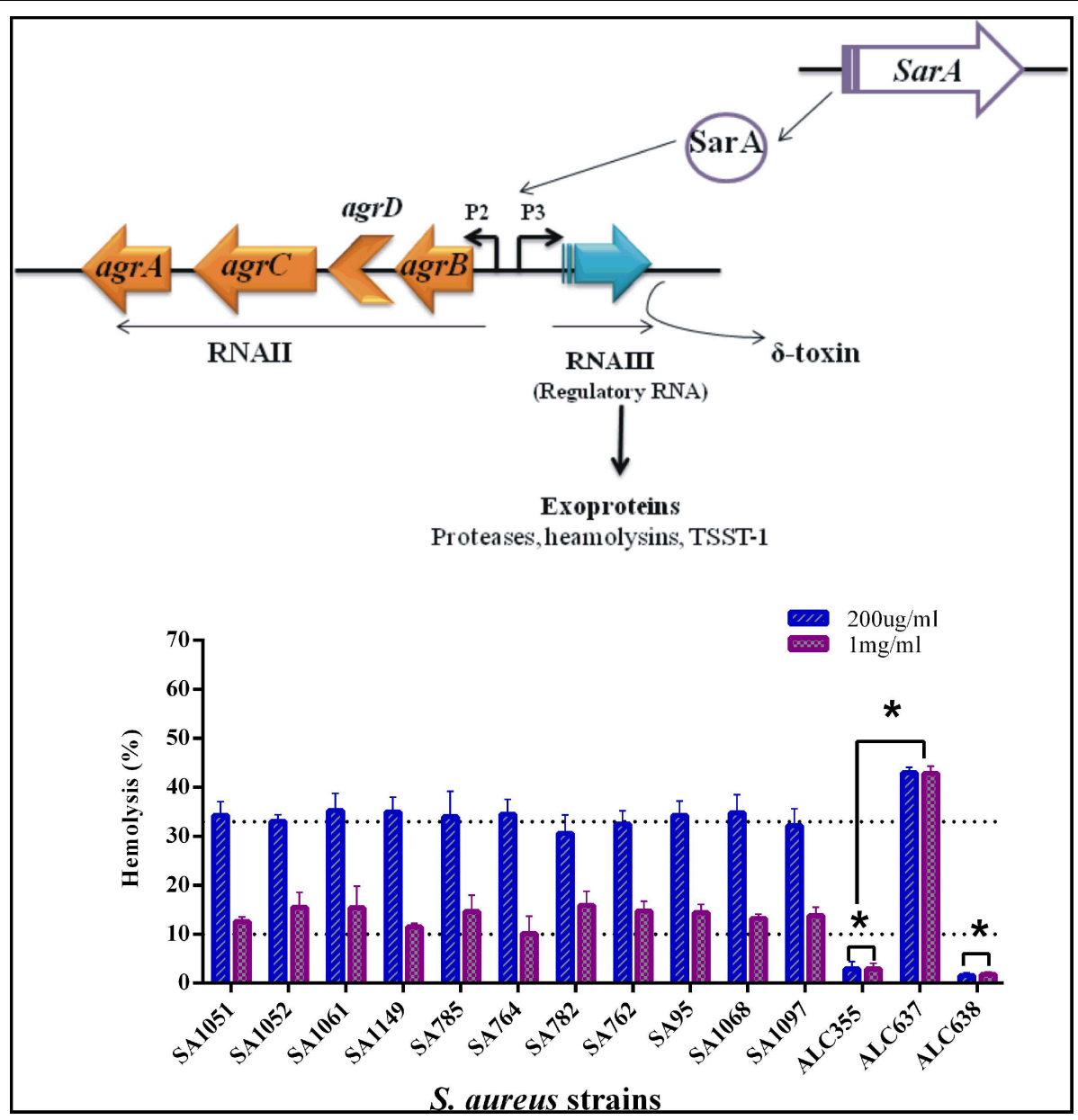

FIGURE 3 | Synergistic in comparison to direct lysis of rabbit blood erythrocytes by $\mathbf{S}$. aureus with SarABI. Culture supernatants were grown in presence $(200 \mu \mathrm{g} / \mathrm{ml}$ and $1 \mathrm{mg} / \mathrm{ml}$, respectively) or absence of SarABI, culture filtered and incubated with a $2 \%$ solution of defibrinated rabbit blood for $30 \mathrm{~min}$ at $37^{\circ} \mathrm{C}$. Hemolysis was measured by determining $\mathrm{OD}_{540} \mathrm{~nm}$ using spectrophotometer and \% lysis calculated from lysed erythrocyte standards, dotted line shown the difference between control and experimental groups. Statistical analysis was performed using the Two-Way ANOVA and Values of $P<0.001$ were considered significant. SarABI significantly decreases the expression of hemolysin in all experimental groups. Asterisk $\left(^{*}\right)$ indicates no weak expression of hemolysin.

\section{Small Molecule SarABI, Attenuate the Bacterial Cell Adherence}

The study was performed to analyze whether the results from extracellular protein secretion and biofilm formation have precisely mirrored the bacterial attachment. So, the $S$. aureus strains listed in Table 1 were compared for their cell adherence capacity on the solid surface. The sarA mutant (Newman sarA::Tn917LTV1) and agr sarA double mutant (Newman $\Delta$ agr::tetM, sarA::Tn917LTV1) strains were observed to be weak biofilm produces and naturally lost their ability to adhere to the solid (polystyrene plate) surface. As expected, the SarABI treatment caused a remarkably reduced adherence in all clinical strains along with the agr mutant under static conditions subjected to an incubation for $30 \mathrm{~min}$ (Figure 4). The data clearly implies the major role of SarA played a major role in the activation of key $S$. aureus surface associated genes.

\section{SarABI Significantly Inhibit Biofilm Formation}

The efficacy of SarABI on biofilm inhibition was studied in situ over time for all the strains using the confocal laser scanning microscopy (CLSM). As shown in Figure 5, the real time measurement of biofilm thickness using time lapse CLSM imaging revealed that untreated clinical isolate, SA1061 has shown a significantly higher biofilm formation with a thickness up to $11 \mu \mathrm{m}$ in elevation over the surface. On the other hand, the SarABI treatment affected the biofilm forming ability of the $S$. aureus clinical isolates, ATCC 25923 and the agr mutant strains SA1061 strain displayed the highest level of total biomass $\left(11 \mu \mathrm{m}^{3} / \mu \mathrm{m}^{2}\right)$ and maximum thickness $(>10 \mu \mathrm{m})$. In contrast, a sharp reduction in biovolume ranging from 0.2 to $1.9 \mu \mathrm{m}^{3} / \mu \mathrm{m}^{2}$ and thickness $(0.2-1.0 \mu \mathrm{m})$ was observed in all the treated strains. Similarly, a fivefold reduction in the roughness coefficient was observed in SarABI treated strains $\left(\sim 0.3 \mu \mathrm{m}^{3} / \mu \mathrm{m}^{2}\right)$ than that of control $\left(1.4 \mu \mathrm{m}^{3} / \mu \mathrm{m}^{2}\right)$. Minimum colony size at the 

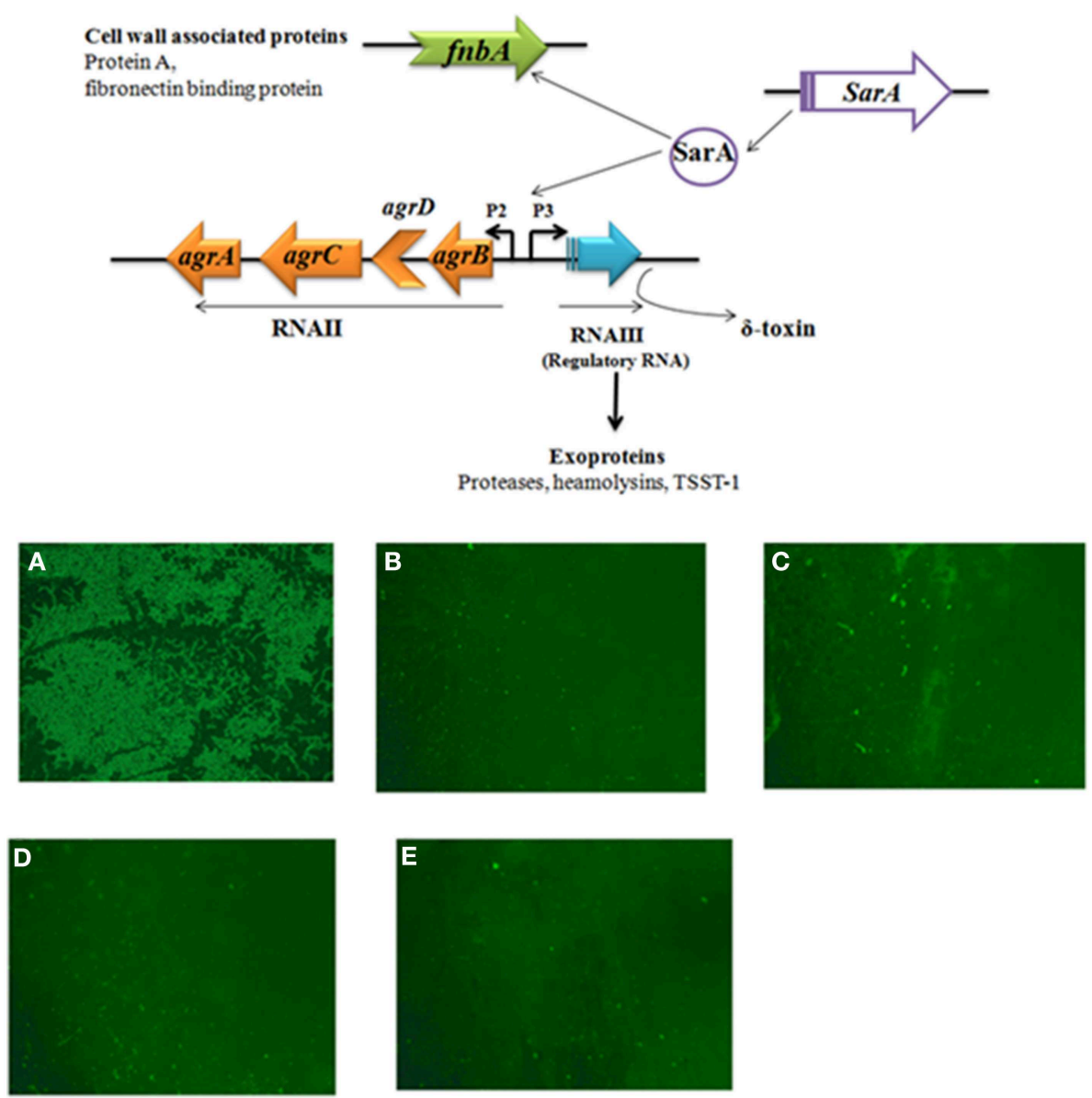

FIGURE 4 | Effective concentration of SarABI reduced for the adherence of Staphylococcus aureus. (A) FITC labeled ATCC 25923 cells $\left(10^{9} \mathrm{CFU}\right)$ were applied to glass slide with $100 \mu$ l of PBS, (B) clinical isolate SA1061, (C) ALC637 (sarA::Tn917LTV1), (D) ALC355 (sagr::tetM),
(E) ALC638 ( $\Delta$ agr::tetM sarA::Tn917LTV1) effective concentration of SarABI were used for the adherence. Cells were incubated for $24 \mathrm{~h}$ at $37^{\circ} \mathrm{C}$, unbound cells were removed by PBS washing and adherent cells observed under the fluorescent microscopy $5 x$. substratum for treated S. aureus strains ranged from 50 to $75 \mu \mathrm{m}^{2}$ as compared to that of control where a considerable larger colony size $\left(6000 \mu \mathrm{m}^{2}\right)$ was observed. Prominently, these results emphasize that the SarA was not a sole regulator to control the biofilm formation as earlier presented but also epitomized as a crucial molecular factors contributing to biofilm structuring in $S$. aureus.

\section{SarABI targets SarA Based Major Virulence Genes Expression}

The SarABI, an inhibitor suppressed the transcriptional activator SarA and negatively controlled it to down-regulate its target genes that influences the adhesion molecules biosynthesis as well as certain toxin production. Hence, inactivation of temporal expression of these genes should invariably affect the expression of RNAIII, $\delta$-hemolysin ( $h l d$ ) and fibronectin binding protein A $(f n b A)$. To determine the fact whether the SarA selective inhibitor (SarABI) has down-regulated the phenotype, biofilm and other virulence factors, the quantitative real time PCR (qPCR) analysis of their transcript levels were also done. As shown in Figure 6, the treatment of highly virulent clinical isolate, SA1061 with SarABI (TSA) at a concentration of $1 \mathrm{mg} / \mathrm{ml}$ greatly reduces the expression of $f n b A, R N A I I I$, and hld as compared to the untreated (CSA) strain. The expression of house-keeping genes, arc and 16s rRNA were also quantified to analyze the effect of SarABI on the survival of $S$. aureus. No significant changes in the expression of those reference genes were observed in both TSA and CSA. Hence the results were consistent to show the SarABI, a well-characterized SarA based inhibitor.

\section{SarABI Treatment in-vivo Diminishes Vascular Graft Infection}

The SarA selective inhibitor, SarABI has proven to show antiadherence effect to potentiate its role to overcome the deviceassociated infections in-vivo. Graft presoaked with $200 \mu \mathrm{g} / \mathrm{ml}$ and $1 \mathrm{mg} / \mathrm{ml}$ showed no sign of infection even though the animals were challenged with a high bacterial load of $2 \times 10^{7} \mathrm{cfu}$ and were analyzed by the colony forming units on blood agar plates (Figure 7). 


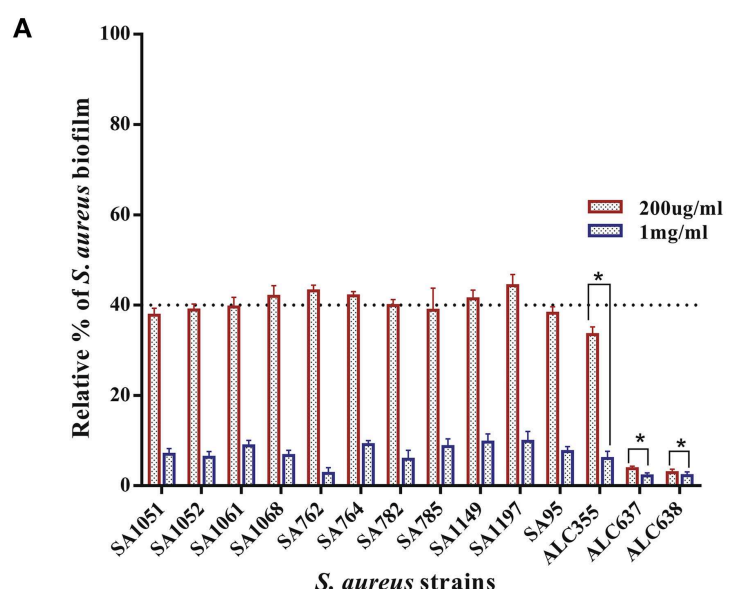

B

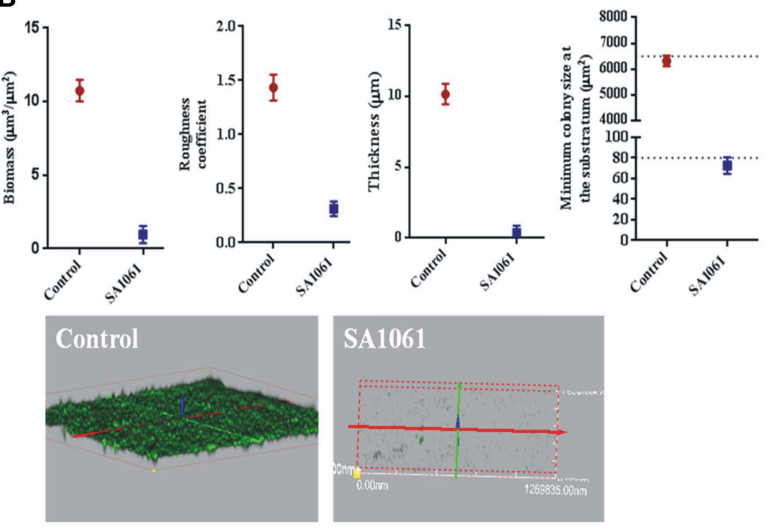

FIGURE 5 | (A) The effect of SarABI on S. aureus attachment to polystyrene In vitro: Cell attachment compared with the clinical isolates and the mutant backgrounds ALC355 ( $\Delta$ agr::tetM), ALC637 (AsarA::Tn917LTV1) single mutants, and the ALC638 ( $\Delta$ agr::tetM, $\Delta$ sar::Tn917LTV1 double mutants) treated with SarABI. S. aureus cultures grown in 96-well microtiter plates were pretreated with SarABI $(200 \mu \mathrm{g} / \mathrm{ml}$ and $1 \mathrm{mg} / \mathrm{ml}$ respectively) and incubated for $24 \mathrm{~h}$. Values show mean numbers of biofilm formation/well, and error bars indicate range, dotted line shown the difference between control and experimental groups. Statistical analysis was performed using the Two-Way ANOVA and values of $P<0.001$ were considered significant. SarABI significantly decreases the expression of biofilm in all experimental groups. Asterisk (*) indicates no detectable expression of biofilm. (B) Quantitative analysis of biofilm development on coverslips by $S$. aureus strains treated with SarABI using CLSM shows biomass, roughness coefficient, thickness and minimal colony at the surface and biofilm production by $S$. aureus as assessed by three dimensional images compared with untreated biofilms. Statistical analysis was performed using the Two-Way ANOVA and values of $P<0.001$ were considered significant. Asterisk $\left(^{*}\right)$ indicates drastically decline fluorescent intensity.

Biochemical analysis of the serum sample was performed to evaluate the SarABI toxicity effect over the function of the renal and the hepatitis systems. The data showed that the SarABI at its effective concentrations $(200 \mu \mathrm{g} / \mathrm{ml}$ and $1 \mathrm{mg} / \mathrm{ml})$ inhibits the $S$. aureus biofilm and virulence but did not affect the normal function of the host cells in comparison with the control (untreated groups) (data not shown). Similarly, histopathological studies of SarABI effect on wistar rats demonstrated that even administration of higher dosage of this drug does not cause any

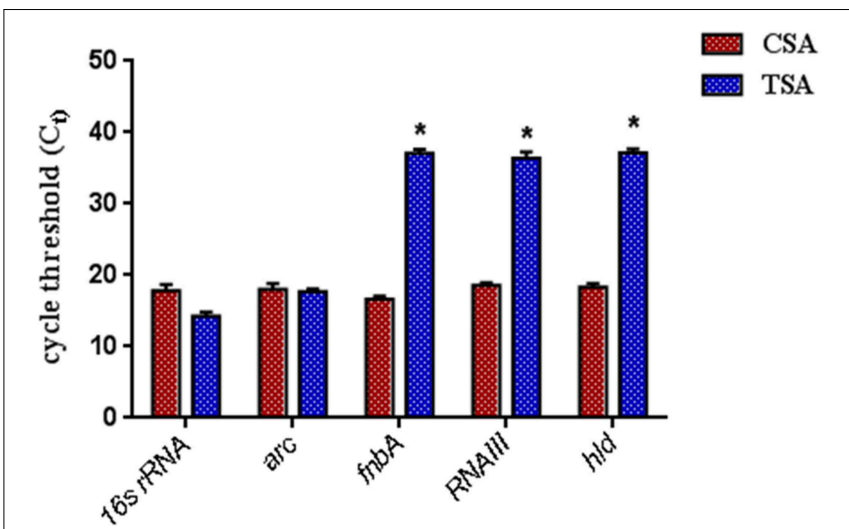

FIGURE 6 | The validation of virulence gene expression level using quantitative RT-PCR. S. aureus were grown overnight at $37^{\circ} \mathrm{C}$ with (TSA, treated S. auerus) or without (CSA, control S. aureus) treated of $1 \mathrm{mg} / \mathrm{ml}$ SarABI in tryptic soy broth. Expression pattern of the fnbA, h/d, and RNAIII were diminished in cells treated with SarABI in comparison to without treated. Statistical analysis was performed using the Two-Way ANOVA and values of $P<0.001$ were considered significant. Asterisk $\left({ }^{*}\right)$ indicates significantly low expression of genes.

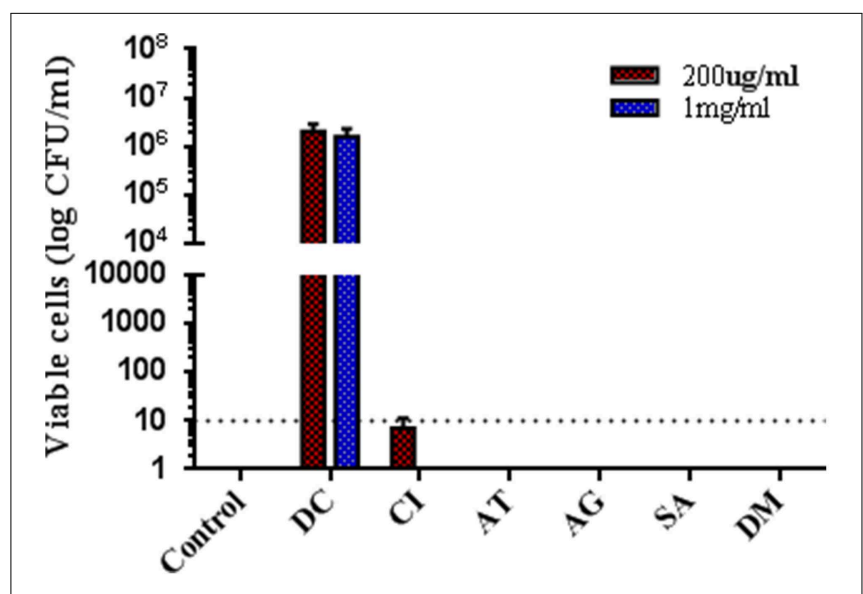

FIGURE 7 | Quantitative microbiological evaluation experiments shows SarABI reduced in-vivo infection. Bacteria $\left(2 \times 10^{7} \mathrm{CFUs}\right)$ were incubated with SarABI for challenge the animals. After 14 day incubation, the graft was removed, and the number of bacteria were determined on blood agar plates. The graph depicts group-I (control), group-II (DC, Diseased control infected with ATCC 25923), group-III (CI, S. aureus clinical isolate with SarABI), group-IV (AT, ATCC 25923 with SarABI), group-V (AG, agr::tetM with SarABI), group-VI (SA, sar::Tn917LTV1 with SarABI) and group-VII (DM, agr::tetM, sar::Tn917LTV1 with SarABI). The low and effective doses of SarABI were used for studied, dotted line shown the difference between control and experimental groups. Statistical analysis was performed using the One-Way ANOVA and values of $P<0.001$ were considered significant. Asterisk (*) indicates no detectable bacteria, suggesting $<10 \mathrm{CFUs} / \mathrm{ml}$.

change in the cellular integration of the liver, kidney, spleen along with the epithelial cells from the graft site while the lesion was observed in adjacent to the epithelial cells from the graft site of the untreated group. All the organs from the drug treated group were found within the histological limits as compared with the control group (Figure 8). 

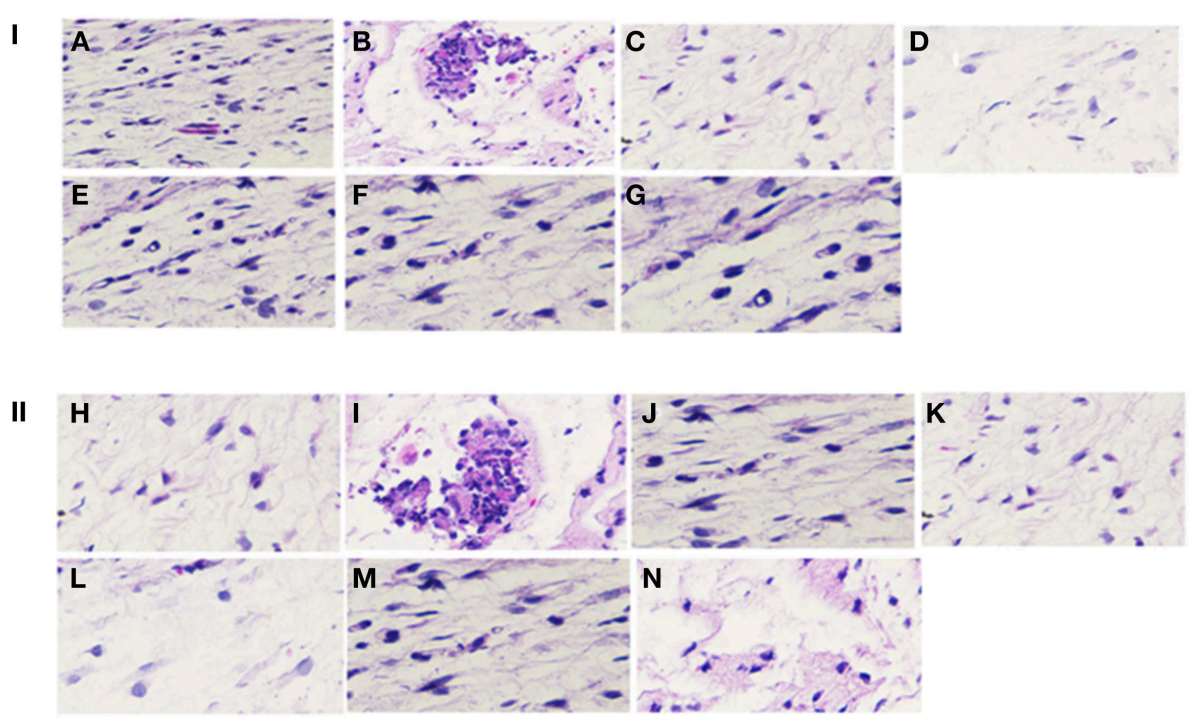

FIGURE 8 | Hematoxylene and eosin stained sections of tissues from implant site. Skin ulcer and necrotic debris was observed in disease control group. Disease control group $(\mathrm{B}, \mathrm{l})$ also exhibits a marked tissue reaction with predominant macrophages, fibroblasts, lymphocytes and neutrophils along with collagen deposition. A fibrous capsule and granulation tissue formation with angiogenesis was predominantly present in the sections. (I,II) represents the $200 \mu \mathrm{g} / \mathrm{ml}$ and $1 \mathrm{mg} / \mathrm{ml}$ SarABI coated vascular grafts experimental groups respectively. Representative samples from different groups treated with SarABI do not show any significant difference from saline control (A, $\mathrm{H}), \operatorname{DC}(\mathrm{B}, \mathrm{I}), \mathrm{Cl}(\mathrm{C}, \mathrm{J})$, AT $(\mathrm{D}, \mathrm{K}), \operatorname{ALC355}(\mathrm{E}, \mathrm{L}), \operatorname{ALC637}(\mathrm{F}, \mathrm{M})$ and $\operatorname{ALC638~(G,~N).~}$

\section{Cell Proliferation Not Affected by SarABI}

The cytotoxic effect of the effective concentration of SarABI $(200 \mu \mathrm{g} / \mathrm{ml}$ and $1 \mathrm{mg} / \mathrm{m})$ on the cell viability were evaluated. A compound usually is considered to have in vitro cytotoxic effect if the particular concentration of drug caused a $50 \%$ cell death. In this study, the cell viability was found to be higher than $95 \%$ in all the drug doses and hence, the SarABI showed no cytotoxic effect.

\section{SarABI Reduces Adherence of $S$. aureus on Hep-2 Cells}

To investigate the role of SarABI on preventing the S. aureus from colonizing the confluent layer of Hep-2 cells, a control (ATCC 25923), clinical isolate and three mutant strains were subjected to CLSM analysis and further the influence of drug (SarABI) over its adherence influenced by various parameters (function of bio volume, roughness coefficient, colony size and mean thickness) were characterized using COMSTAT. The data critically revealed a differential pattern of adherence between the treated and untreated groups to Hep- 2 cells under the same conditions other than the mutant strains (Newman sarA::Tn917LTV1, Newman $\Delta$ agr::tet $M$ and sarA::Tn917LTV)., As shown in the Figure 9, the untreated control produces a biovolume of $11 \mu \mathrm{m}^{3} / \mu \mathrm{m}^{2}$ while the SarABI treatment at a concentration of $1 \mathrm{mg} / \mathrm{ml}$ significantly reduced the biovolume ranging from 0 to $2 \mu \mathrm{m}^{3} / \mu \mathrm{m}^{2}$. The SarABI treatment also reduced the biovolume in the strain, ALC355 while ALC638 did not exhibit any biofilm formation. The minimum colony size at substratum analysis showed that the SarABI treatment reduced the colony size from $6000 \mu \mathrm{m}^{2}$ (untreated) to $50 \mu \mathrm{m}^{2}$. The roughness coefficient was also reduced from 1.4 to nearly 0.3 for all the clinical isolates when treated with SarABI. A higher biofilm was measured in the control and exhibited $11 \mu \mathrm{m}$ thickness in comparison with the treated isolates and the thickness of the biofilm ranged from 0 to $1 \mu \mathrm{m}$. Also the influence of the drug (SarABI) to inhibit the $S$. aureus adherence to the host cell is consistently similar to the effect achieved from our previous adherence assay carried out on the glass surface.

\section{Discussion}

The study demonstrates a unique approach to inhibit the staphylococcal virulence and pathogenesis via., inhibiting the SarA based quorum sensing. The method demonstrated the inhibition of virulence gene expression rather than killing the bacteria. In our previous study, we have used denovo computer-aided discovery of novel SarA selective inhibitors against the target, SarA (PDB ID: 2FRH) (Arya and Princy, 2013b). The SarABI has shown better interaction with the protein, SarA by H-bond acceptor and donor, presence of aromatic rings, functional groups and hydrophobic sites. These interactions provided the SarA-SarABI to form a stable complex as it laid a key role to negatively regulate the SarA interaction to its target promoter regions. The complex was also stabilized by hydrogen bond interactions with the Asp and Glu residues at 88 and 89th position in SarA and ensures to bind to the hydrophobic clamp. Also the presence of fluorine, hydroxyl and amine group might have an imperative role in the inhibition activity.

The compound, SarABI was further tested for its potency at inhibiting biofilm formation against all clinical isolates 

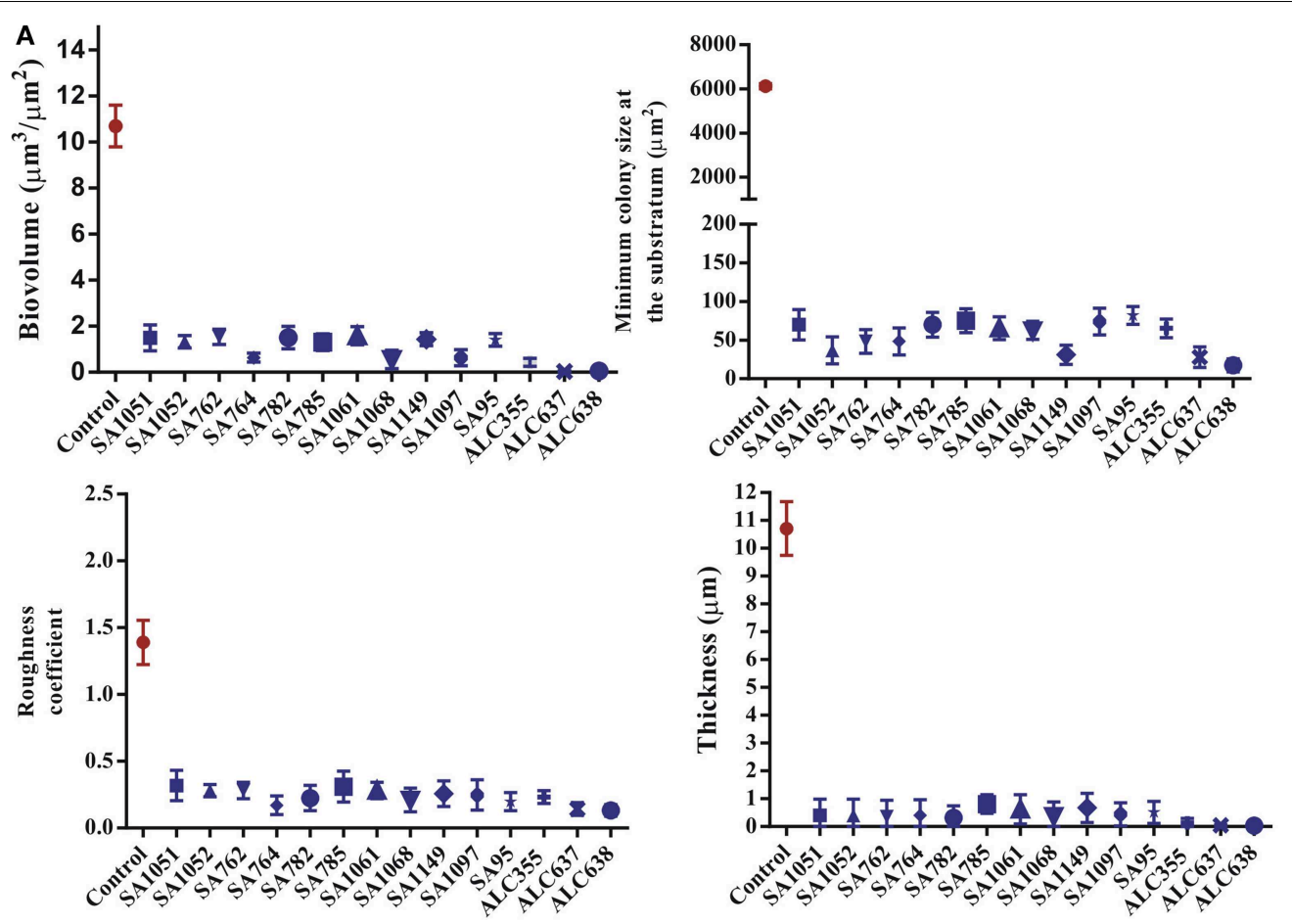

B
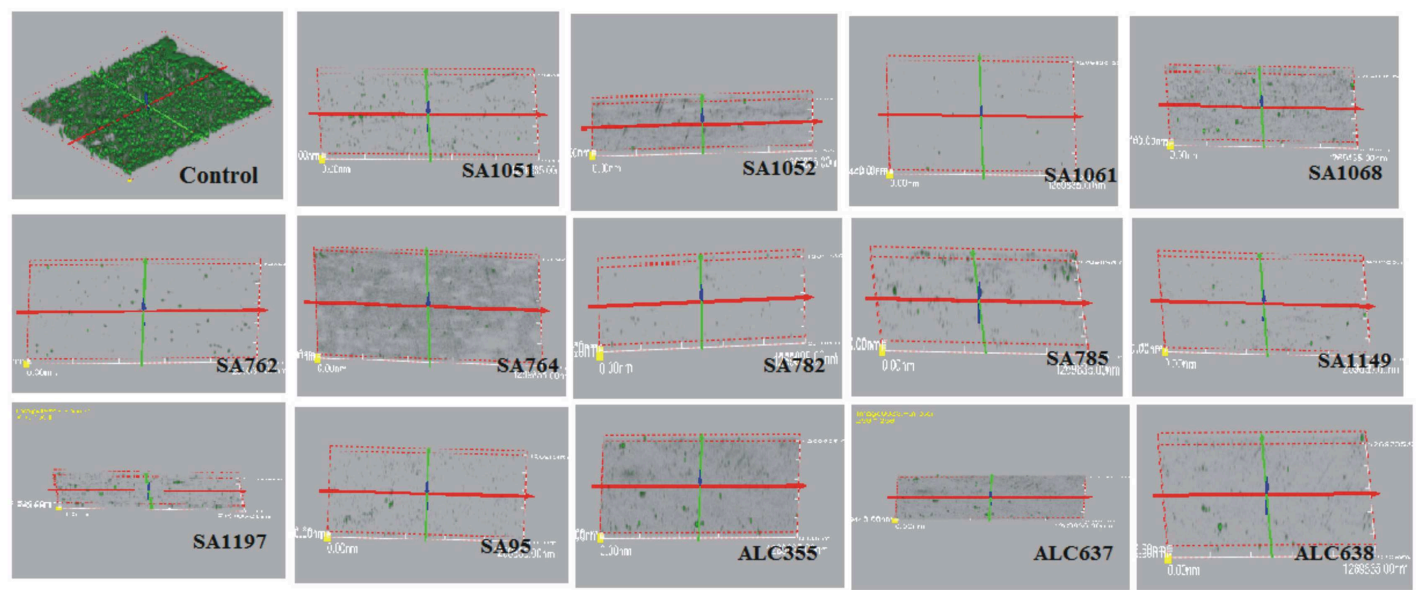

FIGURE 9 | Effect of SarABI on adherence of S. aureus to HEp-2 cell lines. The graph depicts Control (with normal saline), DC (Diseased control contaminated with ATCC 25923), Cl (S. aureus clinical isolate with SarABI), AT (ATCC 25923 with SarABI), ALC355 (agr::tetM with SarABI), ALC637 (sar::Tn917LTV1 with SarABI) and ALC638 (agr::tetM, sar::Tn917LTV1 with SarABI). The effective concentration of SarABI synergistically diminished the adherence of $S$. aureus to HEp-2 cell lines.
(A) Data revealed the significantly reduce in biomass, roughness coefficient thickness and colony at substrate compared with untreated samples. (B) Three-dimensional reconstructed renderings of the $S$. aureus adherence to HEp-2 cells on coverslip. The effective doses of SarABI were used for studied. Statistical analysis was performed using the Two-Way ANOVA and values of $P<0.001$ were considered significant. Asterisk $\left(^{*}\right)$ indicates significant result. and isogenic (agr and sarA) mutant strains. The agr null strain had shown a significant higher expression of biofilm while the expression was reduced when treated with SarABI. The result suggested that the SarABI affects the biofilm on negatively regulating SarA-specific interaction of SarABI to downregulate SarA targeted genes expression that establishes biofilm. Furthermore, the cell adherence assay also revealed that the untreated clinical isolates, agr null strain and the reference strain, ATCC 25923 exhibited a higher adherence on the glass surface while the SarABI treatment inhibited the bacterial cells attachment. The sarA and agr sarA double mutant strains (Newman $\triangle$ agr::tetM, sarA::Tn917LTV1) either treated with SarABI or untreated did not induce biofilm formation. These results confirmed that SarABI acts via opposing the effects of SarA and most likely inhibited the binding of SarA to the DNA (Arya and Princy, 2013b) hence affecting the quorum sensing 
processes. Thus, the SarA selective inhibitor, SarABI was found to be very effective in suppression of the process of cell attachment, proliferation and invasion.

The biofilm formation in $S$. aureus is a multistep process that commences with the cell attachment and then the expression of genes responsible for extracellular toxins production (Lister and Horswill, 2014). An array of hemolytic proteins is frequently isolated from $S$. aureus and is among the most significant staphylococcal toxins. The hemolysins and associated proteins are pore-forming staphylococcal virulence factors that significantly contribute in bacterial infections (Tavares et al., 2014). A concentration-dependent inhibition of hemolytic activity was observed when the clinical isolates were treated with SarABI.

As the effective concentration of $200 \mu \mathrm{g} / \mathrm{ml}\left(\mathrm{MBIC}_{50}\right)$ and high dose of $1 \mathrm{mg} / \mathrm{ml}\left(\mathrm{MBIC}_{90}\right)$ of SarABI were found to inhibit the biofilm formation as observed in the MBIC assay, we furthermore sought to define and analyze the impact of the drug on the biofilm formation using fluorescence labeling of the biofilm. There was substantial reduction in the degree and kinetics of biofilm formation with the strains treated with SarABI. In static biofilms, biovolume, roughness coefficient, colony size and mean thickness values were considerably higher in the ATCC 25923, agr mutant, Newman $\Delta a g r:: t e t M$ and all clinical isolates compared with those values of the treated strains.

The expression of the various genes including RNAIII, fnbA and hld plays an imperative role in staphylococcal pathogenesis including biofilm formation, proliferation and evasion (Beenken et al., 2010). The transcription of RNAIII was greatly reduced in the $S$. aureus culture supplemented with SarABI and hence changed the temporal expression of various virulence factors. The lack of adherence and biofilm formation in sarA mutant (Newman sarA::Tn917LTV1) and SarABI treated clinical isolates also suggested that the activation of fibronectin-binding proteins promotes their adherence to the surface or host epithelial cells is under the direct control of SarA. This was remarkably substantiated by the RT-qPCR data where the down-regulation of all those genes was detected during exponential phase after treatment, demonstrating SarABI interference with SarA to show its response to its target genes at the transcriptional level. As expected, the expressions of all three transcripts were correlated with the decreased biofilm formation and hemolysin activity of all clinical strains.

The cytotoxicity of the SarABI was also evaluated and results demonstrated that the SarABI did not show cytotoxic

\section{References}

Aboshady, I., Raad, I., Shah, A. S., Vela, D., Dvorak, T., Safi, H. J., et al. (2012). A pilot study of a triple antimicrobial-bonded Dacron graft for the prevention of aortic graft infection. J. Vasc. Surg. 3, 794-801. doi: 10.1016/j.jvs.2012. 02.008

Andrey, D. O. (2010). Control of the Staphylococcus aureus toxic shock tst promoter by the global regulator SarA. J. Bacteriol. 192, 6077-6085. doi: 10.1128/JB.00146-10

Arciola, C. R., Campoccia, D., Speziale, P., Montanaro, L., and Costerton, J. W. (2012). Biofilm formation in Staphylococcus implant infections. A review effect to HepG-2 cell line even at its higher concentrations. Remarkably, SarABI a novel drug to show its effect on inhibiting a quorum regulator, SarA and further to downregulate several gene expression that establishes biofilm and virulence without affecting the cell growth. So, this approach would block an independent pathway other than the vital pathways responsible for their life cycle. The approach toward finding an "antivirulent" drug in the control of pathogenic bacteria imposes a control over its pathogenic phenotypes rather than developing selective pressure and drug resistance.

\section{Author Contributions}

All the authors have equally contributed to the manuscript.

\section{Acknowledgments}

We thank University Grant Commission, Govt. of India for providing fellowship to Ms. Rekha Arya under Rajiv Gandhi National Fellowship Scheme and excellent management of SASTRA University. We are also grateful to Professor Christiane Wolz (Institute for Medical Microbiology and Hygiene, University of Tübingen, Germany) for sending us the mutant strains used in this study.

\section{Supplementary Material}

The Supplementary Material for this article can be found online at: http://journal.frontiersin.org/article/10.3389/fmicb. 2015.00416/abstract

Figure S1 | Chemical characterization of the Trans-4-[(2, 4-difluorobenzyl) amino]cyclohexanol (SarABI) after an $8 \mathrm{~h}$ reaction with catalyst $\mathrm{NaOH}$. The distribution of characteristic aromatic and aliphatic protons according to their occurrence in those regions was confirmed with proton NMR. The hump region denotes the presence of $\mathrm{NH}$ group.

Figure S2 $\mid{ }^{13} \mathbf{C}$ NMR Spectra of SarABI. The carbon NMR spectrum was used to confirm the two benzene rings along with the diamine aliphatic region according to their prediction space in the spectra.

Figure S3 | Characteristic FTIR absorbencies of the SarABI. Major vibrational bands interpreted to be due to: $\mathrm{H}$-bonded $\mathrm{OH}$-stretching $\left(3415.42 \mathrm{~cm}^{-1}\right)$.

Figure S4 | Mass Spectroscopy Determination of SarABI was analyzed by GC/MS in $\mathrm{Cl}$ mode using Helium flow for ionization to determine molecular weights. The sample was pyrolysed at $290^{\circ} \mathrm{C}$, and the resulting vapor was injected into gas chromatograph mass spectrometer (GC-MS). The different gaseous products were separated by the GC, and analyzed by MS in the GC column outlet and identify the products by their mass spectrum. of molecular mechanisms and implications for biofilm-resistant materials. Biomaterials 33, 5967-5982. doi: 10.1016/j.biomaterials.2012.05.031

Arya, R., and Princy, S. A. (2013a). An insight into pleiotropic regulators Agr and Sar: molecular probes paving the new way for antivirulent therapy. Future Microbiol. 10, 1339-1353. doi: 10.2217/fmb.13.92

Arya, R., and Princy, S. A. (2013b). Computational approach to design small molecule inhibitors and identify SarA as a potential therapeutic candidate. Med. Chem. Res. 22, 1856-1865. doi: 10.1007/s00044-012-0185-9

Balaban, N., Gov, Y., Bitler, A., and Boelaert, J. R. (2003). Prevention of Staphylococcus aureus biofilm on dialysis catheters and adherence to human cells. Kidney Int. 63, 340-345. doi: 10.1046/j.1523-1755.2003.00733.x 
Barnes, R., and Chetter, I. (2012). Infection in prosthetic material. Surgery (Oxford) 30, 667-672. doi: 10.1016/j.mpsur.2012.10.002

Beenken, K. E., Mrak, L. N., Griffin, L. M., Zielinska, A. K., Shaw, L. N., Rice, K. C., et al. (2010). Epistatic relationships between sarA and agr in Staphylococcus aureus biofilm formation. PLoS ONE 5:e10790. doi: 10.1371/journal.pone.0010790

Bellows, C. F., Wheatley, B. M., Moroz, K., Rosales, S. C., and Morici, L. A. (2011). The effect of bacterial infection on the biomechanical properties of biological mesh in a rat model. PLoS ONE 6:e21228. doi: 10.1371/journal.pone.0021228

Boles, B. R., Thoendel, M., Roth, A. J., and Horswill, A. R. (2010). Identification of genes involved in polysaccharide-independent Staphylococcus aureus biofilm formation. PLoS ONE 5:e10146. doi: 10.1371/journal.pone.0010146

Bose, J. L., Lehman, M. K., Fey, P. D., and Bayles, K. W. (2012). Contribution of the Staphylococcus aureus Atl AM and GL Murein hydrolase activities in cell division, autolysis, and biofilm formation. PLOS ONE 7:e42244. doi: 10.1371/journal.pone.0042244

Chen, H. Y., Chen, C. C., Fang, C. S., Hsieh, Y. T., Lin, M. H., and Shu, J. C. (2011). Vancomycin activates $\sigma(B)$ in vancomycin-resistant Staphylococcus aureus resulting in the enhancement of cytotoxicity. PLoS ONE 6:e24472. doi: 10.1371/journal.pone.0024472

Cheung, A. L., Bayer, A. S., Zhang, G., Gresham, H., and Xiong, Y. Q. (2004). Regulation of virulence determinants in vitro and in vivo in Staphylococcus aureus. FEMS Immunol. Med. Microbiol. 1, 1-9 doi: 10.1016/S09288244(03)00309-2

Cheung, A. L., Nishina, K., and Manna, A. C. (2008). SarA of Staphylococcus aureus binds to the sarA promoter to regulate gene expression. J. Bacteriol. 190, 2239-2243. doi: 10.1128/JB.01826-07

Chien, Y., Manna, A. C., Projan, S. J., and Cheung, A. L. (1999). SarA, a global regulator of virulence determinants in Staphylococcus aureus, binds to a conserved motif essential for sar-dependent gene regulation. J. Biol. Chem. 52, 37169-37176. doi: 10.1074/jbc.274.52.37169

Chomczynski, P., and Sacchi, N. (2006). The single-step method of RNA isolation by acid guanidinium thiocyanate-phenol-chloroform extraction: twenty-something years on. Nat. Protoc. 2, 581-585 doi: 10.1038/nprot.2006.83

Coraça-Huber, D. C., Fille, M., Hausdorfer, J., Pfaller, K., and Nogler, M. (2012). Staphylococcus aureus biofilm formation and antibiotic susceptibility tests on polystyrene and metal surfaces. J. Appl. Microbiol. 112, 1235-1243. doi: $10.1111 /$ j.1365-2672.2012.05288.x

Daghighi, S., Sjollema, J., van der Mei, H. C., Busscher, H. J., and Rochford, E. T. (2013). Infection resistance of degradable versus non-degradable biomaterials: an assessment of the potential mechanisms. Biomaterials 34, 8013-8017. doi: 10.1016/j.biomaterials.2013.07.044

De Latour, F. A., Amer, L. S., Papanstasiou, E. A., Bishop, B. M., and van Hoek, M. L. (2010). Antimicrobial activity of the Naja atra cathelicidin and related small peptides. Biochem. Biophys. Res. Commun. 396, 825-830. doi: 10.1016/j.bbrc.2010.04.158

Dean, S. N., Bishop, B. M., and van Hoek, M. L. (2011). Natural and synthetic cathelicidin peptides with anti-microbial and anti-biofilm activity against Staphylococcus aureus. BMC Microbiol. 11:114. doi: 10.1186/1471-2180-11-114

George, S. E., Chikkamadaiah, R., Durgaiah, M., Joshi, A. A., Thankappan, U. P., Madhusudhana, S. N., et al. (2012). Biochemical characterization and evaluation of cytotoxicity of antistaphylococcal chimeric protein P128. BMC Res Notes 5:280. doi: 10.1186/1756-0500-5-280

Gov, Y., Bitler, A., Dell'Acqua, G., Torres, J. V., and Balaban, N. (2001). RNAIII inhibiting peptide (RIP), a global inhibitor of Staphylococcus aureus pathogenesis: structure and function analysis. Peptides 22, 1609-1620.doi: 10.1016/S0196-9781(01)00496-X

Hochbaum, A. I., Kolodkin-Gal, I., Foulston, L., Kolter, R., Aizenberg, J., and Losick, R. (2011). Inhibitory effects of D-amino acids on Staphylococcus aureus biofilm development. J. Bacteriol. 193, 5616-5622. doi: 10.1128/JB.05534-11

Kiran, M. D., Adikesavan, N. V., Cirioni, O., Giacometti, A., Silvestri, C., Scalise, G., et al. (2008). Discovery of a quorum-sensing inhibitor of drug-resistant staphylococcal infections by structure-based virtual screening. Mol. Pharmacol. 73, 1578-1586. doi: 10.1124/mol.107.044164

Krut, O., Utermöhlen, O., Schlossherr, X., and Krönke, M. (2003). Strain-specific association of cytotoxic activity and virulence of clinical Staphylococcus aureus isolates. Infect. Immun. 71, 2716-2723. doi: 10.1128/IAI.71.5.2716-2723.2003

Legout, L., Delia, P., Sarraz-Bournet, B., Rouyer, C., Massongo, M., Valette, M., et al. (2014). Factors predictive of treatment failure in staphylococcal prosthetic vascular graft infections: a prospective observational cohort study: impact of rifampin. BMC Infect. Dis. 14:228. doi: 10.1186/1471-2334-14-228

Legout, L., Sarraz-Bournet, B., D’Elia, P. V., Devos, P., Pasquet, A., Caillaux, M., et al. (2012). Characteristics and prognosis in patients with prosthetic vascular graft infection: a prospective observational cohort study. Clin. Microbiol. Infect. 18, 352-358. doi: 10.1111/j.1469-0691.2011.03618.x

Lister, J. S., and Horswill, A. R. (2014). Staphylococcus aureus biofilms: recent developments in biofilm dispersal. Front. Cell. Infect. Microbiol. 4:178. doi: 10.3389/fcimb.2014.00178

Liu, Y., Manna, A. C., Pan, C. H., Kriksunov, I. A., Thiel, D. J., Cheung, A. L., et al. (2006). Structural and function analyses of the global regulatory protein SarA from Staphylococcus aureus. Proc. Natl. Acad. Sci. U.S.A. 103, 2392-2397. doi: 10.1073/pnas.0510439103

Opperman, T. J., Kwasny, S. M., Williams, J. D., Khan, A. R., Peet, N. P., Moir, D. T., et al. (2012). Aryl rhodanines specifically inhibit staphylococcal and enterococcal biofilm formation. Antimicrob. Agents Chemother. 53, 4357-4367. doi: 10.1128/AAC.00077-09

Periasamy, S., Joo, H. S., Duong, A. C., Bach, T. H. L., Tan, V. Y., Chatterjee, S. S., et al. (2012). How Staphylococcus aureus biofilms develop their characteristic structure. Proc. Natl. Acad. Sci. U.S.A. 109, 1281-1286. doi: 10.1073/pnas.1115006109

Roberts, C., Anderson, K. L., Murphy, E., Projan, S. J., Mounts, W., Hurlburt, B., et al. (2006). Characterizing the effect of the Staphylococcus aureus virulence factor regulator, SarA, on log-phase mRNA half-lives. J. Bacteriol. 188, 2593-2603 doi: 10.1128/JB.188.7.2593-2603.2006

Sully, E. K., Malachowa, N., Elmore, B. O., Alexander, S. M., Femling, J. K., Gray, B. M., et al. (2014). Selective chemical inhibition of agr quorum sensing in Staphylococcus aureus promotes host defense with minimal impact on resistance. PLoS Pathog. 6:e1004174. doi: 10.1371/journal.ppat.1004174

Tavares, A., Nielsen, J. B., Boye, K., Rohde, S., Paulo, A. C., Westh, H., et al. (2014). Insights into $\alpha$-hemolysin (Hla) evolution and expression among Staphylococcus aureus clones with hospital and community origin. PLoS ONE 7:e98634. doi: 10.1371/journal.pone.0098634

Trotonda, M. P., Manna, A. C., Cheung, A. L., Lasa, I., and Penadés, J. R. (2005). SarA positively controls bap-dependent biofilm formation in Staphylococcus aureus. J. Bacteriol. 187, 5790-5798. doi: 10.1128/JB.187.16.5790-5798.2005

Wang, R., Khan, B. A., Cheung, G. Y., Bach, T. H. L., Jameson-Lee, M., Kong, K. F., et al. (2011). Staphylococcus epidermidis surfactant peptides promote biofilm maturation and dissemination of biofilm-associated infection in mice. J. Clin. Invest. 121, 238-248. doi: 10.1172/JCI42520

Wolz, C., Pöhlmann-Dietze, P., Steinhuber, A., Chien, Y. T., Manna, A., Van Wamel, W., et al. (2000). Agr-independent regulation of fibronectin binding protein(s) by the regulatory locus sar in Staphylococcus aureus. Mol. Microbiol. 36, 230-243. doi: 10.1046/j.1365-2958.2000.01853.x

Conflict of Interest Statement: The authors declare that the research was conducted in the absence of any commercial or financial relationships that could be construed as a potential conflict of interest.

Copyright (c) 2015 Arya, Ravikumar, Santhosh and Princy. This is an open-access article distributed under the terms of the Creative Commons Attribution License (CC $B Y)$. The use, distribution or reproduction in other forums is permitted, provided the original author(s) or licensor are credited and that the original publication in this journal is cited, in accordance with accepted academic practice. No use, distribution or reproduction is permitted which does not comply with these terms. 